\title{
Pembuatan Biogas Dari Limbah Campuran Eceng Gondok Dan Kotoran Sapi Dengan Proses Hidrolisis Asam Sulfat
}

\author{
Kiagus Ahmad Roni*1, Netty Herawati², Siti Amira Anggraini ${ }^{3}$ \\ *123Program Studi Teknik Kimia, Fakultas Teknik, Universitas Muhammadiyah Palembang \\ Jl. Jend. A. Yani 13 Ulu Plaju Palembang, telp. 0711-513022 / fax. 0711-513078 \\ e-mail : "kiagusaroni@gmail.com
}

\begin{abstract}
The scarcity of LPG gas in Indonesia has resulted in an increase in the price of LPG. Since the change in people's habits in Indonesia from using kerosene to epliji gas for their daily needs, the need for LPG gas has increased. Therefore, alternative energy is needed to overcome this problem. One of them is biogas. In this research, water byacinth is used as the main raw material for making biogas. The cellulose contained in water byacinth is then hydrolyzed so that glucose is obtained which will later be fermented with the help of bacteria, and methane gas is obtained as biogas. Cow manure is used as a biostarter which is a source of bacteria in the fermentation stage. This study aims to determine the optimum composition and duration of fermentation. Based on the results of the research, it was found that the composition of water hyacinth and water was the most optimum at 7 days of fermentation, and for the optimum composition, at a ratio of 1:3 for 7 days and 50\%: 50\%, it was able to produce biogas up to $302 \mathrm{~mL}$ for 21 days. With a COD concentration of $21.40 \mathrm{mg} / \mathrm{L}$ and a TSS of $38.30 \mathrm{mg} / \mathrm{L}$.
\end{abstract}

Keywords: alternative energy, biogas, biostarter, water hyacinth

\section{PENDAHULUAN}

Biogas atau gas bio merupakan salah satu jenis energi yang dapat dibuat dari banyak bahan buangan dan bahan sisa, semacam sampah, kotoran ternak, jerami, eceng gondok serta banyak bahan-bahan lainnya lagi [1]. Beberapa hal yang menarik dari pada teknologi biogas adalah kemampuannya untuk membentuk biogas dari limbah organik yang jumlahnya berlimpah dan tersedia secara bebas. Sejumlah bahan organik dapat digunakan bersama-sama dengan beberapa persyaratan produksi gas atau pertumbuhan normal bakteri metan yang sesuai. Salah satu limbah yang bisa dijadikan bahan pembuatan biogas adalah eceng gondok [2].

Biogas dapat dibuat dengan menggunakan eceng gondok, tetapi kendala yang dihadapi dalam pengolahan eceng gondok menjadi biogas adalah keberadaan lignin dan hemiselulosa serta struktur dari selulosa yang sulit untuk diuraikan dalam kondisi anaerobik sehingga akan menurunkan yield biogas. Selain itu keberadaan lignin/cellulal material dapat menyebabkan scum problem [3]. Oleh karena itu perlu dilakukan pretreatment untuk mereduksi kristal selulosa, meningkatkan porositas bahan dan menguraikan lignin dan hemiselulosa [4].

Pada penelitian sebelumnya telah dilakukan pembuatan biogas dari eceng gondok dan kotoran sapi yang dibuat dengan proses hidrolisis menggunakan $\mathrm{HCl}$. Akan tetapi penelitian ini kurang optimum karena menghasilkan biogas tidak banyak. Untuk memperbaiki penelitian dari literatur sebelumnya maka proses hidrolisis yang akan dilakukan menggunakan $\mathrm{H}_{2} \mathrm{SO}_{4}$. Hal ini dikarenakan kemurnian $\mathrm{H}_{2} \mathrm{SO}_{4}$ lebih tinggi dibandingkan $\mathrm{HCl}$.

Permasalahan pada penelitian ini yaitu pengaruh komposisi eceng gondok-air, dan enceng gondok-kotoran sapi terhadap lama fermentasi volume, titik embun dan uji nyala api pada biogas. Serta pengaruh COD dan TSS terhadap volume biogas yang dihasilkan. Adapun tujuan dari penelitian ini yaitu mengetahui kualitas dari biogas yang dihasilkan terhadap komposisi bahan baku yang mempengaruhi.

\section{Enceng gondok}

Eceng gondok (Eichbornia crassipes (mart) solm.) merupakan tanaman gulma di wilayah perairan yang hidup terapung pada air yang dalam atau mengembangkan perakaran di dalam lumpur pada air yang dangkal. Eceng gondok 
berkembangbiak dengan sangat cepat, baik secara vegetatif maupun generatif. Perkembangbiakan dengan cara vegetatif dapat melipat ganda dua kali dalam waktu 7-10 hari.

Divisio : Embryophytasi Phonogama

Sub Divisio : Spermathopyta

Klas : Monocotyledoneae

Ordo : Ferinosae

Famili : Pontederiaccae Genus : Eichhornia

Spesies : Eichhornia crassipes (Mart) Solm. [5]

Tanaman ini memiliki banyak kandungan materi yang dapat difermentasi dan mampu menghasilkan biogas. Kandungan yang paling berperan tersebut adalah hemiselulosa dan selulosa. Eceng gondok memiliki $43 \%$ untuk hemiselulosa dan selulosa sebesar $17 \%$. Hemiselulosa tersebut merupakan jenis polisakarida kompleks yang menjadi penyusun struktur organik dan merupakan bahan utama yang dpaat dikonversi menjadi biogas. [6]

\section{Limbah kotoran sapi}

Limbah ternak adalah sisa buangan suatu kegiatan usaha peternakan seperti usaha pemeliharaan ternak, rumah potong hewan, dan pengolahan produk ternak. Limbah tersebut meliputi limbah padat dan limbah cair seperti feses, urine, sisa makanan, embrio, kulit telur, lemak, darah, bulu, kuku, tulang, dan tanduk. Berkembangnya usaha peternakan mengakibatkan banyaknya limbah yang dihasilkan, selain menghasilkan feses dan urine, dari proses pencernaan ternak menghasilkan gas metan $\left(\mathrm{CH}_{4}\right)$ yang cukup tinggi. [7]

Gas metan ini adalah salah satu unsur yang diperlukan dalam pembuatan briket. Berdasarkan hasil analisis diperoleh bahwa kotoran sapi mengandung selulosa $(22,59 \%)$, hemiselulosa $(18,32 \%)$, lignin $(10,20 \%)$, total karbon organik (34,72\%), total nitrogen $(1,26 \%)$, ratio C:N (27,56:1), P (0,73\%), dan K (0,68\%) [8].

\section{Hidrolisis asam}

Hidrolisis adalah jenis reaksi kimia yang terjadi antara air dan senyawa lain. Selama reaksi, ikatan kimia akan rusak di kedua molekul, menyebabkan mereka menjadi pecah. Molekul air terpecah untuk membentuk ion hidrogen $\left(\mathrm{H}^{+}\right)$dan hidroksida $\left(\mathrm{OH}^{-}\right)$, dan molekul lainnya terbagi menjadi dua bagian sederhana, juga dengan muatan positif dan negatif. Ion $\mathrm{H}^{+}$dan $\mathrm{OH}^{-}$melekat pada masing - masing bagian ini. Reaksi ini terjadi ketika beberapa senyawa ionik, misalnya, asam tertentu, basa, dan garam, larut dalam air; mereka terlibat dalam proses yang sangat penting untuk kehidupan; mereka digunakan dalam beberapa proses industri yang penting, seperti pembuatan sabun; dan mereka memainkan peranan penting pada pelapukan batuan.[9].

Di dalam metode hidrolisis asam, biomassa lignoselulosa dipaparkan dengan asam pada suhu dan tekanan tertentu selama waktu tertentu, dan menghasilkan monomer gula dari polimer selulosa dan hemiselulosa. Beberapa asam yang umum digunakan untuk hidrolisis asam antara lain asam sulfat $\left(\mathrm{H}_{2} \mathrm{SO}_{4}\right)$, asam perklorat, dan HCl.[10].

Asam sulfat merupakan asam yang paling banyak diteliti dan dimanfaatkan untuk hidrolisis asam. Hidrolisis asam dapat dikelompokkan menjadi hidrolisis asam kuat dan hidrolisis asam lemah. Hidrolisis asam pekat merupakan teknik yang sudah dikembangkan cukup lama. Broconnot di tahun 1819 pertama menemukan bahwa selulosa bisa dikonversi menjadi gula yang dapat difermentasi dengan menggunakan asam pekat. Hidrolisis asam encer juga dikenal dengan hidrolisis asam dua tahap dan merupakan metode hidrolisis yang banyak dikembangkan dan diteliti saat ini. Hidrolisis asam encer pertama kali dipatenkan oleh H.K. Moore pada tahun 1919. Potongan (chip) kayu dimasukkan ke dalam tangki kemudian diberi uap panas pada suhu $300^{\circ} \mathrm{F}$ selama satu jam. Selanjutnya dihidrolisis dengan menggunakan asam fosfat.[11]

Kelemahan dari hidrolisis asam encer adalah degradasi gula hasil di dalam reaksi hidrolisis dan pembentukan produk samping yang tidak diinginkan. Beberapa senyawa inhibitor yang dapat terbentuk selama proses hidrolisis asam encer adalah furfural, 5-hydroxymethylfurfural (HMF), asam levulinik, asam asetat, asam format, asam uronat, asam 4-hydroxybenzoic, asam vanilik, vanillin, phenol, cinnamaldehyde, formaldehida, dan beberapa senyawa lain [12]. 


\section{METODE PENELITIAN}

Pada penelitian ini alat yang digunakan dalam pembuatan biogas berupa Kantong plastik $3 \mathrm{~kg}$ sebagai penampung gas, Selang gas untuk menyalurkan gas, regulator untuk melihat tekanan gas, pipa PVC sebagai alat penghubung untuk memasukkan substrat eceng gondok dan kotoran sapi dan pembuangan substrat eceng gondok, isolasi pipa untuk merekatkan pipa, galon air dengan volume $15 \mathrm{~L}$.

Penelitian skala laboratorium dilakukan di laboratorium proses industri kima UMP Palembang. Eceng gondok dan limbah kotoran sapi digunakan sebagai bahan baku substrat dalam reaktor (jerigen) anaerob. Bahan yang digunakan dalam penelitian eceng gondok, kotoran sapi, air, $\mathrm{H}_{2} \mathrm{SO} 4$ dan $\mathrm{NaOH}$. Berikut Rancangan Penelitian ini dapat digambarkan pada Gambar 1 dan 2

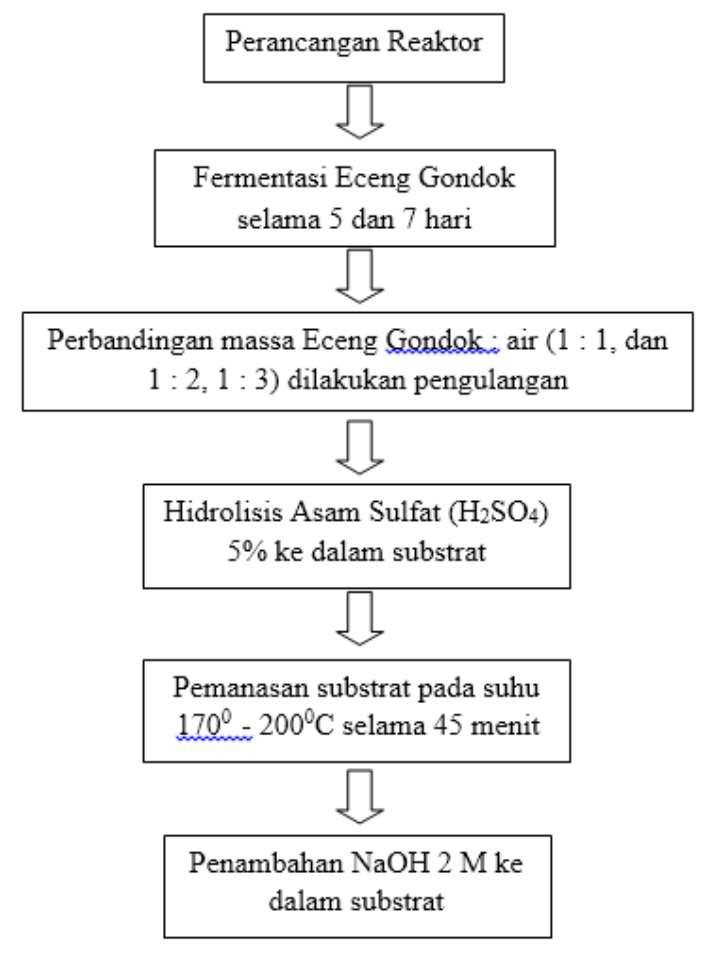

Gambar 1. Tahap Fermentasi Eceng Gondok

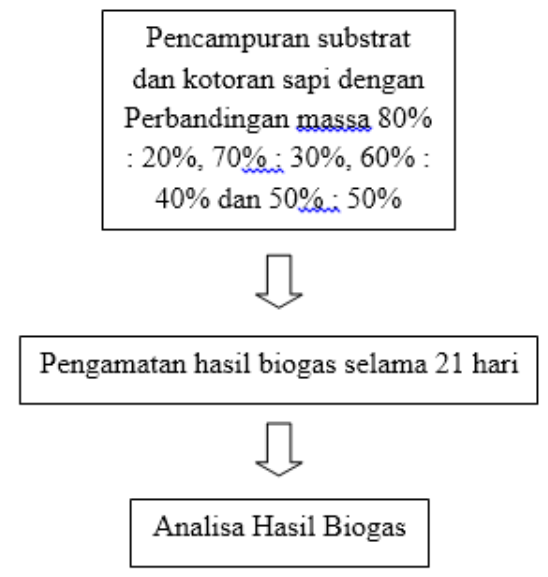

Gambar 2. Tahap Metanogenik

\section{HASIL DAN PEMBAHASAN}

61 Pembuatan Biogas Dari Limbah Campuran Eceng Gondok Dan Kotoran Sapi Dengan Proses Hidrolisis Asam Sulfat 
Hasil penelitian ini akan memaparkan volume biogas yang diamati selama 21 hari. Pengamatan dilakukan 3 hari sekali diambil pada hari ke- 3, 6, 9, 12,15, 18 dan 21. Selain itu juga dipaparkan pula hasil analisa COD, TSS, titik embun gas dan uji nyala api.

Kenaikan volume biogas dipengaruhi oleh beberapa faktor, diantaranya biostarter yang ditambahkan, lama waktu fermentasi eceng gondok, perbandingan eceng gondok dan air serta faktor - faktor lainnya. Penelitian ini memfokuskan variasi campuran eceng gondok dan kotoran sapi yang paling banyak menghasilkan volume biogas, lama fermentasi eceng gondok dan komposisi eceng gondok dan air yang paling optimum. Pengukuran volume biogas ini dilakukan dengan metode penurunan air pada wadah pastik yang didalamnya diletakkan gelas ukur yang terbalik. Tujuannya untuk mengetahui penurunan air dalam wadah plastik yang menunjukkan terdapat adanya gas. Berikut pembahasan dari volume biogas yang akan dijelaskan dari gambar dibawah ini.

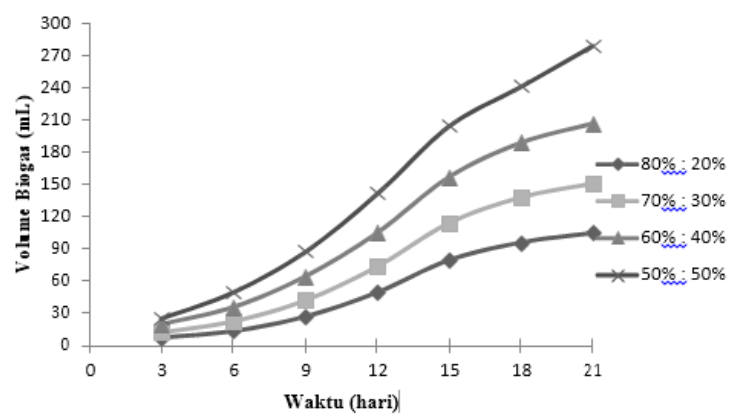

Gambar 3. Pengaruh Komposisi Eceng Gondok dan air $1: 3$ Hidrolisis Asam Sulfat Pada Proses Fermentasi Selama 7 Hari Dengan Variasi Campuran Kotoran Sapi Terhadap Volume Biogas

Komposisi eceng gondok dan kotoran sapi 50\%:50\% menghasilkan biogas yang paling banyak yaitu $302 \mathrm{~mL}$. Waktu fermentasi selama 7 hari merupakan waktu yang paling baik untuk menghasilkan biogas yang paling banyak. Selama waktu 3 hari mikroba yang tumbuh selama proses pembusukkan baru mengalami tahap adaptasi. Jangka waktu fermentasi 4 hari -7 hari mikroba yang tumbuh semakin banyak. Akan tetapi, bila sudah memasuki waktu lebih dari 7 hari maka mikroba sudah mulai mati sehingga proses fermentasi sudah tidak efektif lagi. Selain itu juga perbandingan komposisi eceng gondok dan air yang paling optimum yaitu $1: 3$ karena substrat yang semakin encer memiliki keunggulan untuk mengurangi konsentrasi inhibitor menjadi semakin kecil shingga proses pertumbuhan mikroba akan semakin cepat. Jadi, berdasarkan keenam grafik dapat diketahui bahwa kondisi yang paling optimum untuk menghasilkan biogas yaitu pada perbandingan komposisi eceng gondok dan air $1: 3$, lama fermentasi 7 hari dan komposisi campuran eceng gondok dan kotoran sapi 50\%:50\%.

\section{Analisa COD}

Kebutuhan oksigen kimiawi atau yang lebih dikenal sebagai Chemical Oxygen Demand (COD) adalah banyaknya oksigen yang dibutuhkan untuk mengoksidasi seluruh bahan organik (bahan yang terurai dan sukar terurai) secara kimia dengan menggunakan oksidator kuat.

Volume biogas yang diambil sebagai perbandingan terhadap COD adalah volume biogas yang paling terakhir hari ke-21. Pengaruh COD terhadap volume biogas dapat kita lihat dari gambar grafik di bawah ini. 


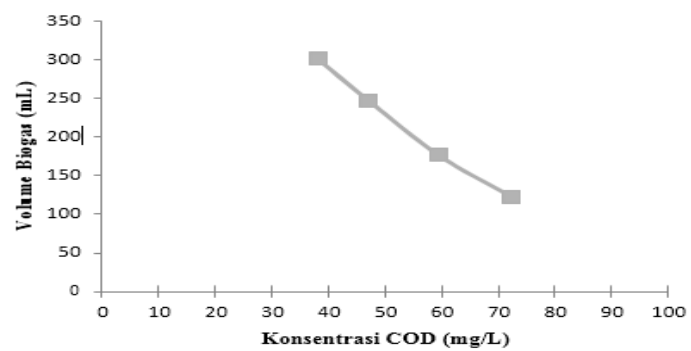

Gambar 4. Pengaruh Komposisi Eceng Gondok dan Air 1: 3 Dengan Proses Hidrolisis Asam Sulfat dan Lama Fermentasi 7 Hari Dengan Variasi Campuran Kotoran Sapi Terhadap Konsentrasi COD

Berdasarkan gambar 4 menunjukkan bahwa semakin rendah konsentrasi pada COD maka semakin banyak biogas yang dihasilkan. Pada komposisi eceng gondok dan air sebanyak $1: 3$ dengan lama proses fermentasi selama 7 hari mampu menghasilkan biogas sebanyak $340 \mathrm{ml}$ dengan konsentrasi COD yang paling rendah dibandingkan dengan grafik-grafik sebelumnya yaitu $21,40 \mathrm{mg} / \mathrm{L}$. Hal ini menunjukkan bahwa pada komposisi eceng gondok dan air ini merupakan komposisi yang paling optimum dikarenakan substrat eceng gondok yang paling encer mampu mengecilkan konsentrasi pada inhibitor bakteri metanogenensis. Hal inilah yang membuat bakteri ini cepat mengalami pertumbuhan sehingga konsentrasi eceng gondok semakin rendah. selain itu juga, lama fermentasi selama 7 hari merupakan waktu fermentasi yang paling optimum dalam menghasilkan biogas karena waktu fermentasi 7 hari menghasilkan mikroba yang paling banyak.[13].

\section{Analisa TSS}

Penelitian ini menggunakan analisa TSS untuk mengetahui penurunan kadar logam pada eceng gondok sebagaimana diketahui bahwa eceng gondok mampu menyerap logam berat dengan cepat. Oleh karena itu penggunaan analisa ini akan melihat penurunan atau kenaikan pada TSS setelah dilakukan proses hidrolisis pada pembuatan biogas ini.

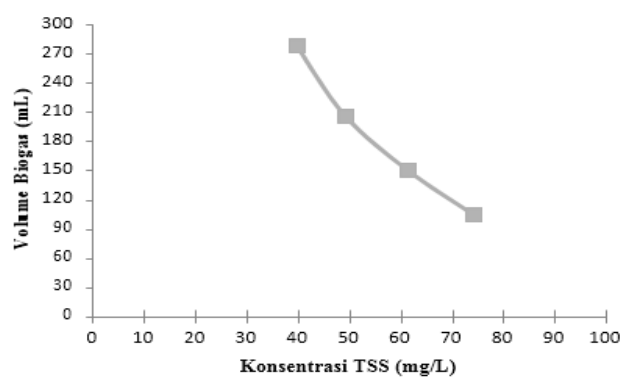

Gambar 5. Pengaruh Komposisi Eceng Gondok dan Air 1: 3 Dengan Proses Hidrolisis Asam Sulfat dan Lama Fermentasi 7 Hari Dengan Variasi Campuran Kotoran Sapi Terhadap Konsentrasi TSS

Gambar 5 merupakan grafik yang paling optimum menurunkan kadar TSS dan menghasilkan volume biogas yang paling optimum. Hasil yang optimum yaitu menghasilkan konsentrasi TSS paling rendah 38,30 mg/L dengan volume biogas sebanyak $302 \mathrm{~mL}$. Hal ini dikarenakan lama fermentasi selama 7 hari mampu menghasilkan mikroba paling banyak dengan mengecilkan konsentrasi inhibitor bakteri metanogenesis sehingga mikroba tumbuh dengan cepat. Banyaknya mikroba ini yang terdapat pada eceng gondok maupun kotoran sapi ini akan didegradasi sehingga nilai TSS cenderung menurun.[14].

\section{Analisa titik embun gas}

Titik embun gas merupakan metode analisa yang dilakukan dengan pengamatan secara fisik untuk menunjukkan adanya embun atau tidak di dalam gas. Gas yang mengandung embun menunjukkan adanya air pada gas tersebut. 
Begitupun sebaliknya, jika dari hasil pengamatan gas tidak terdapat embun berarti gas tersebut tidak mengandung air. Berdasarkan pengamatan secara fisik mengenai titik embun gas yang dituliskan pada tabel 4.3. didapatkan bahwa kondisi yang paling optimum yaitu pada perbandingan massa eceng gondok dan air $1: 3$ dengan lama fermentasi 5 hari dan 7 hari serta pada komposisi massa eceng gondok dan air dengan lama fermentasi 7 hari dengan variasi massa campuran eceng gondok dan kotoran sapi 60\%: 40\% dan 50\%:50\%. Hal ini menunjukkan bahwa dengan komposisi tersebut gas dikatakan berkualitas sangat baik.

Variasi lainnya yaitu pada perbandingan massa eceng gondok dan air $1: 1$ dengan proses fermentasi 5 dan 7 hari serta perbandingan massa eceng gondok dan air $1: 2$ dengan lama fermentasi 5 hari dan 7 hari pada variasi campuran eceng gondok dan kotoran sapi 80\%: 20\% dan 70\%:30\% menunjukkan masih terdapatnya embun pada masing - masing gas. Hal ini menunjukkan bahwa gas pada perbandingan tersebut masih mengandung air. Bila gas tersebut masih mengandung air maka gas akan cepat habis karena berkontak langsung dengan air.

\section{Uji nyala}

Uji nyala api ini merupakan metode analisa yang dilakukan pengamatan secara fisik untuk menentukan cepat atau lambat nyala api pada suatu gas. Uji nyala api ini dilakukan dengan cara memercikan api pada gas ke dalam kantong plastik lalu kita amati apakah gas cepat menyala atau tidak. Gas yang cepat menyala pada umumnya gas yang berjumlah banyak.

Berdasarkan pengamatan yang dilakukan secara fisik yang ditulis pada tabel 4.3. didapatkan kondisi yang optimum dimana gas sangat cepat menyala yaitu pada perbandingan ecen gondok dan air $1: 3$ dengan proses fermentasi selama 7 hari serta variasi campuran eceng gondok dan kotoran sapi pada perbandingan 50\%:50\%. Hal ini menunjukkan pada kondisi tersebut volume biogas yang dihasilkan paling banyak yaitu masing - masing $248 \mathrm{ml}$ dan $302 \mathrm{ml}$ selama 21 hari sehingga dapat dikatakan semakin banyak gas yang dihasilkan makin besar tekanannya dan nyala api biogas tersebut pun sangat cepat. Selain itu juga, pada kondisi tersebut tidak terdapat embun atau dapat dikatakan tidak mengandung air. Hal ini menunjukkan bahwa tidak adanya embun pada suatu gas maka gas tersebut akan cepat menyala. Kondisi yang lainnya yaitu pada perbandingan massa eceng gondok dan air 1:1,1 : pada proses fermentasi 5 dan 7 hari nyala api pada biogas lambat. Hal ini dikarenakan pada kondisi tersebut masih mengandung embun sehingga gas tersebut tidak cepat menyala.

\section{KESIMPULAN}

Berdasarkan penelitian dapat disimpulkan bahwa Eceng gondok memiliki manfaat sebagai energi alternatif bahan bakar gas di masyarakat dalam bentuk biogas. Komposisi eceng gondok dan air yang paling optimum untuk menghasilkan biogas, tanpa mengandung air dan cepat menyala adalah $1: 3$ dengan lama proses fermentasi selama 7 hari.

Komposisi eceng gondok dan kotoran sapi yang paling optimum untuk menghasilkan biogas adalah pada perbandingan 50\%:50\% yang mampu memproduksi hingga $302 \mathrm{~mL}$ biogas selama 21 hari tanpa mengandung air dan titik nyala api sangat cepat. Dapat dikatakan pula bahwa semakin banyak jumlah biostarter yang ditambahkan maka semakin banyak volume biogas yang dihasilkan tetapi jumlahnya tidak boleh melebihi dari bahan baku utama.Nilai COD dan TSS semakin rendah maka biogas yang diproduksi semakin banyak. Hal ini terlihat bahwa dengan konsentrasi COD 21,40 mg/L dan konsentrasi TSS 38,30 mg/L mampu menghasilkan biogas sampai $302 \mathrm{~mL}$.

\section{DAFTAR PUSTAKA}

[1] Astuti Nurfitri, Tri Retnaningsih Soeprobowati dan Budiyono. 2014. Produksi Biogas Dari Eceng Gondok (Eicchornia crassipes (Mart.)Solms) dan Limbah Ternak Sapi di Rawapening. Magister Ilmu Lingkungan. Undip. Semarang.

[2] Azay Ragsul Saputri dan Yulinah Trihadiningrum. 2010. Pemanfaatan Biomassa Eceng Gondok Dari Kolam Pengolahan Greywater Sebagai Penghasil Biogas. Fakultas Teknik Sipil. ITS. Surabaya.

[3] Galuh Ratri S. 2009. Optimasi Pembuatan Biogas dan Pupuk Organik. Dari Tumbuban Eceng Gondok (Eichbornia Crasïpes (Mart.) Solms.) Dalam Skala Lapangan. Program Studi Biologi SITH. ITB. Bandung 
[4] Prajayana, F. I., Romli, M dan Suprihatin. (2011). Kajian Konversi Limbah Padat Jerami Padi Manjadi Biogas. Tesis. Institut Pertanian Bogor, Bogor.

[5] Winarnih Panggih, Yulinah Trihadiningrum dan Soeprijanto. 2012. Produksi Biogas Dari Eceng Gondok. Fakultas Teknik Kimia. ITS. Surabaya.

[6] Yonatahan Arnold, Avianda Rusba Pprasetya dan Bambang Pramudono. 2013. Produksi Biogas Dari Eceng Gondok (Eichhornia crassipes) : Kajian Konsistensi dan pH Terbadap Biogas yang Dihasilkan. Jurnal Teknologi Kimia dan Industri Vol. 2, No. 2 211-215. http://translationjournal.net/journal//65naive.htm, 16 Agustus 2014.

[7] Sakinah, Abu Bakar Tawali dan Musrizal Muin. 2009. Pengarub Konsentrasi Biostarter Kotoran Sapi dan Kotoran Ayam Pada Produksi Biogas Dengan Menggunakan Limbah Jerami Padi. Agroteknologi. Universitas Hasanuddin. Makassar.

[8] Shankar, G dan Tondon, G. 1986. A Laboratory Study Of Biogas Production From Water Hyacinth. World Journal of Microbiology and Biotechnology 1, 72-77.

[9] Masriani, dkk. 2014. Pengaruh Waktu Tinggal Terhadap Reaksi Hidrolisis Pada Pra- Pembuatan Biogas Dari Limbah Cair Pabrik. Kelapa Sawit. Jurnal Dinamika Penelitian Industri Vol. 5 23-30. Magister Teknik Kimia. USU. Medan.

[10] Lateng, N. (2010). Pengaruh Jumlah Biostarter dan Waktu Fermentasi pada Pemanfaatan Limbah Kulit Buah Kakao Sebagai Bahan Baku Pembuatan Biogas. Tesis. Program Pascasarjana. UNHAS, Makassar.

[11] Malik, A. 2006. Environmental Challenge Vis a Vis Opportunity : The Case Of Water Hyacinth. Environment International Vol. 33 122-138 Elseiver ltd.

[12] Rahman, B. (2005). Biogas Sebagai Sumber Energi Alternatif. http://www.energi.lipi.go.id/utama.cgi?cetakartikel\&1123717100

[13] Suriawiria dan Unus, H. (2002). Menuai Biogas dari Limbah, (online), (http://www.pikiranrakyat.com/squirrelmail, diakses 15 Januari 2012).

[14] Sutarno dan Firdaus, S. (2007). Analisis Prestasi Produksi Biogas (CH4) dari Polyethilene Biodigester Berbahan Baku Ternak Sapi. FTI-UII. 